\title{
Freeze tolerance in the wood frog Rana sylvatica is associated with unusual structural features in insulin but not in glucagon
}

\section{J M Conlon, K Yano, N Chartrel ${ }^{1}$, H Vaudry $^{1}$ and K B Storey ${ }^{2}$}

Regulatory Peptide Center, Department of Biomedical Sciences, Creighton University School of Medicine, Omaha, Nebraska 68178-0405, USA

${ }^{1}$ European Institute for Peptide Research, Laboratory of Cellular and Molecular Neuroendocrinology, INSERM U-413, UA CNRS, University of Rouen, 76821 Mont-Saint-Aignan, France

${ }^{2}$ Institute of Biochemistry and Department of Biology, Carleton University, Ottawa, Ontario, Canada K1S 5B6

(Requests for offprints should be addressed to J M Conlon)

\begin{abstract}
The wood frog Rana sylvatica utilises glucose, derived from hepatic glycogen, as a cyroprotectant in order to survive freezing during winter hibernation, and glycogenolysis is initiated by hormonal and/or neural stimuli. The primary structure of insulin was determined from $R$. sylvatica and from two species of freeze-intolerant Ranid frogs $R$. catesbeiana (American bullfrog) and $R$. ridibunda (European green frog). All three insulins contain a dipeptide (Lys-Pro) extension to the N-terminus of the A-chain. The amino acid sequences of insulins from $R$. catesbeiana and $R$. ridibunda differ by only one residue (Asp for Glu at B21) but $R$. sylvatica insulin differs from $R$. catesbeiana insulin at A12 $(\mathrm{Thr} \rightarrow$ Met), A23 (Asn $\rightarrow$ Ser), B5 (Tyr $\rightarrow$ His $)$ and B13 (Glu $\rightarrow$ Asp). The residue at A23 (corresponding to A21 in human insulin) has been otherwise fully conserved during evolution and the residue at
\end{abstract}

B13 has been strongly conserved in tetrapods. Insulin isolated from specimens of $R$. sylvatica that had been frozen for $24 \mathrm{~h}$ and from control animals that had not been frozen had the same structure, showing that freezing did not alter the pathway of post-translational processing of proinsulin. $R$. sylvatica glucagon was isolated in two molecular forms. Glucagon-29 was identical to $R$. catesbeiana glucagon-29 and contains only one amino acid substitution ( $\mathrm{Thr} \rightarrow \mathrm{Ser}$ ) compared with human glucagon. Glucagon-36 represents glucagon-29 extended from its C-terminus by Lys-Arg-Ser-GlyGly-Ile-Ser and is identical to $R$. catesbeiana glucagon-36. We speculate that selective changes in the structure of the insulin molecule may contribute to the anomalous regulation of glycogen phosphorylase in the wood frog.

Fournal of Molecular Endocrinology (1998) 21, 153-159

\section{INTRODUCTION}

The wood frog Rana sylvatica is the only North American frog found north of the Arctic Circle and it has developed a survival strategy that enables it to withstand the freezing of extracellular body fluids during winter hibernation (Storey 1990). The animal accumulates glucose (plasma concentrations between 200 and $500 \mathrm{mM}$ ) as a cryoprotectant that is derived primarily from massive hepatic glycogen stores (up to $180 \mathrm{mg} / \mathrm{g}$ wet tissue weight) built up before hibernation. Glycogenolysis is triggered immediately when ice begins to form on the skin of the frog and glucose is distributed to all organs by the action of the cardiovascular system before heartbeat and blood flow finally stop (Storey 1987a, Layne et al. 1989). Freezing is associated with a rapid and sustained activation of hepatic glycogen phosphorylase, the enzyme responsible for glycogen mobilization (Storey \& Storey 1985), an increase in the number and/or activity of glucose transporters in the animal's vital organs (King et al. 1993), and a decrease in the intracellular concentration of glucose 2,6-bisphosphate, the major regulator of metabolic flux through the glycolytic pathway (Storey 1987b).

The extreme and sustained hyperglycemia in the freezing-exposed wood frog suggests that the hormonal regulation of the enzymes involved with 
glucose metabolism in this species must be modified from the usual mechanisms operating in vertebrates that efficiently control the rates of glucose production and disposal. The precise hormonal and/or neural stimuli that trigger hepatic glycogenolysis are not known. Studies with dispersed hepatocytes have shown that neither low temperature exposure nor extracellular freezing directly stimulates the activation of phosphorylase (Storey \& Mommsen 1994). $R$. sylvatica hepatocytes respond to porcine glucagon and epinephrine with an increase in glucose output (Mommsen \& Storey 1992) but attempts to measure changes in circulating levels of these hormones during freezing have not been successful (Storey et al. 1992). The aim of the present study was to purify insulin and glucagon from an extract of the pancreas of the wood frog in order to determine whether anomalous structural features in the endogenous hormones may contribute to the anomalous regulation of glucose homeostasis in this species. The primary structures of these hormones are compared with the corresponding amino acid sequences of insulin and glucagon isolated from two species of freeze-intolerant Ranid frogs, the European green frog $R$. ridibunda and the American bullfrog $R$. catesbeiana.

\section{MATERIALS AND METHODS}

\section{Tissue extraction}

One-year-old male specimens of Rana sylvatica (5-7 g) were collected from the Ottawa region in April 1997. Pancreatic tissue $(0 \cdot 27 \mathrm{~g}$ wet weight $)$ was removed from animals $(n=200)$ that had been acclimated at $5{ }^{\circ} \mathrm{C}$ in a moist environment without food. Animals were killed by a single pithing and the tissues were immediately frozen in liquid nitrogen. Pancreatic tissue $(0.29 \mathrm{~g})$ was also removed from animals $(n=200)$ that had been frozen for $24 \mathrm{~h}$ at $-3{ }^{\circ} \mathrm{C}$ as described (Storey 1987a). The animals were killed while still frozen. Adult male specimens ( $n=200)$ of Rana ridibunda (40-50 g) and adult specimens $(n=40)$ of Rana catesbeiana $(400-500 \mathrm{~g})$ of both sexes were obtained from a commercial source. The pancreas $(7 \cdot 3 \mathrm{~g}$ from $R$. ridibunda and $13.0 \mathrm{~g}$ from $R$. catesbeiana) was removed from pithed animals and the tissues were immediately frozen on dry ice. Tissues were homogenized with ethanol/0.7 $\mathrm{M} \mathrm{HCl}$ $(3 / 1, \mathrm{v} / \mathrm{v} ; 20 \mathrm{ml} / \mathrm{g})$ using a Waring blender. After centrifugation $\left(1600 \mathrm{~g}\right.$ for $30 \mathrm{~min}$ at $\left.4{ }^{\circ} \mathrm{C}\right)$, ethanol was removed from the supernatants under reduced pressure. Peptide material was isolated from the extracts using Sep-Pak C-18 cartridges (Waters Associates, Milford, MA, USA) as previously described (Conlon et al. 1996). Bound material was eluted with acetonitrile/water/trifluoroacetic acid $(70: 29 \cdot 9: 0 \cdot 1)$ and lyophilized.

\section{Radioimmunoassay}

Insulin-like immunoreactivity was measured using an antiserum raised against pig insulin as previously described (Flatt \& Bailey 1981). Glucagon-like immunoreactivity was measured with an antiserum directed against a site in the central region of porcine glucagon as previously described (Conlon \& Thim 1985).

\section{Purification of $R$. sylvatica and $R$. ridibunda insulins}

The same procedure was used for the purification of insulin from both species and so only the method used for the isolation of the peptide from the extract of pancreas from specimens of $R$. sylvatica that had not been frozen is described in detail. The extract, after partial purification on Sep-Pak cartridges, was redissolved in $0 \cdot 1 \%(\mathrm{v} / \mathrm{v})$ trifluoroacetic acid/water $(5 \mathrm{ml})$ and injected onto a $1 \times 25 \mathrm{~cm}$ Vydac 218TP510 C-18 reversed-phase HPLC column (Separations Group, Hesperia, CA, USA) equilibrated with $0 \cdot 1 \%$ trifluoroacetic acid/water at a flow rate of $2 \mathrm{ml} / \mathrm{min}$. The concentration of acetonitrile in the eluting solvent was raised to $21 \%$ over $10 \mathrm{~min}$ and to $49 \%$ over $60 \mathrm{~min}$ using linear gradients. Absorbance was measured at 214 and $280 \mathrm{~nm}$ and fractions (1 $\mathrm{min})$ were collected. Insulin-like immunoreactivity was measured at a dilution of 1:30. $R$. sylvatica insulin was purified to near homogeneity, as assessed by a symmetrical peak shape, by successive chromatographies on a $0.46 \times 25 \mathrm{~cm}$ Vydac 214TP54 C-4 column and a $0.46 \times 25 \mathrm{~cm}$ Vydac 219TP54 phenyl column. The columns were eluted at a flow rate of $1.5 \mathrm{ml} / \mathrm{min}$ and the concentration of acetonitrile in the eluting solvent was raised from $21 \%$ to $42 \%$ over 40 min using a linear gradient.

\section{Purification of $R$. catesbeiana insulin}

The pancreatic extract, after partial purification on Sep-Pak cartridges, was redissolved in $1 \mathrm{M}$ acetic acid $(2 \mathrm{ml})$ and chromatographed on a $1.6 \times 90 \mathrm{~cm}$ column of Sephadex G-25 (Pharmacia Biotech, Uppsala, Sweden) equilibrated with $1 \mathrm{M}$ acetic acid. The column was eluted at a flow rate of $24 \mathrm{ml} / \mathrm{h}$ and fractions $(2.0 \mathrm{ml})$ were collected. Absorbance was measured at $280 \mathrm{~nm}$. The concentration of insulinlike immunoreactivity in the fractions was determined at a dilution of $1: 30$. Fractions containing insulin were pooled and injected onto a $1 \times 25 \mathrm{~cm}$ Vydac 218TP510 C-18 reversed-phase HPLC 
column equilibrated with $0 \cdot 1 \%(\mathrm{v} / \mathrm{v})$ trifluoroacetic acid/water at a flow rate of $2 \mathrm{ml} / \mathrm{min}$. The column was eluted under the same conditions used for the purification of $R$. sylvatica insulin. $R$. catesbeiana insulin was purified by successive chromatographies on a $0.46 \times 25 \mathrm{~cm}$ Vydac 214 TP54 C-4 column and a $0.46 \times 25 \mathrm{~cm}$ Vydac 219 TP54 phenyl column using the same elution conditions as previously.

\section{Purification of $R$. sylvatica glucagon}

The peaks designated $G_{1}$ and $G_{2}$, containing glucagon-like immunoreactivity (Fig. 1A), were rechromatographed on a $0.46 \times 25 \mathrm{~cm}$ Vydac 214 TP54 C-4 column and on a $0.46 \times 25 \mathrm{~cm}$ Vydac 219TP54 phenyl column under the same conditions used for the purification of insulin.

\section{Structural analysis}

Purified insulin samples (approximately $1 \mathrm{nmol}$ ) isolated from frozen and control specimens of $R$. sylvatica and from $R$. catesbeiana and $R$. ridibunda were separately incubated for $6 \mathrm{~h}$ at room temperature with dithiothreitol $(2 \mathrm{mg})$ in $0.1 \mathrm{M}$ Tris- $\mathrm{HCl}-$ $6 \mathrm{M}$ guanidine hydrochloride buffer $\mathrm{pH} 7 \cdot 5(0 \cdot 4 \mathrm{ml})$ under an atmosphere of argon. Cysteine residues were derivatized by addition of 4-vinylpyridine $(3 \mu \mathrm{l})$ and the pyridylethylated A- and B-chains of insulin were separated on a $0.46 \times 25 \mathrm{~cm}$ Vydac C-4 column under the conditions used for the purification of intact insulin (Fig. 2A). Amino acid compositions were determined by precolumn derivatization with phenylisothiocyanate using an Applied Biosystems model 420A derivatizer (Foster City, CA, USA), followed by separation of the phenylthiocarbamyl amino acids by reversed phase HPLC (Bidlingmeyer et al. 1984). Hydrolysis in $5 \cdot 7 \mathrm{M}$ hydrochloric acid $\left(24 \mathrm{~h}\right.$ at $\left.110{ }^{\circ} \mathrm{C}\right)$ of approximately $500 \mathrm{pmol}$ peptide was carried out. The primary structures of the peptides were determined by automated Edman degradation using an Applied Biosystems model 471A sequenator modified for on-line detection of phenylthiohydantoin amino acids under gradient elution conditions. Standard operating procedures were used (Applied Biosystem model 471A Protein Sequencer User's Manual) and the detection limit was 1 pmol.

\section{RESULTS}

\section{Purification of insulins}

The elution profiles on a semipreparative Vydac C-18 column of the extracts of the pancreata of $R$. sylvatica (non-frozen animals) and $R$. ridibunda, after partial purification on Sep-Pak cartridges, and of the extract of $R$. catesbeiana pancreas after partial purification by gel permeation chromatography, are shown in Fig. 1 (panels A-C). In each case, relatively prominent peaks were identified in the chromatograms that were associated with insulinlike immunoreactivity. The elution profile of the extract of the pancreata of viable specimens of $R$. sylvatica that had been frozen for $24 \mathrm{~h}$ was almost superimposible on that shown in Fig. 1A and the retention time of the insulin-containing peak was the same. Consequently, the peaks of $R$. sylvatica insulin from the frozen and control specimens were combined for further purification. $R$. sylvatica insulin was purified to near homogeneity, as assessed by a symmetrical peak shape, by successive chromatographies on an analytical Vydac C-4 column (Fig. 2A) and an analytical Vydac phenyl column (Fig. 2B). The final yield of pure peptide was $2.5 \mathrm{nmol}$. The final yield of pure insulin from $R$. ridibunda was $5 \mathrm{nmol}$ and from $R$. catesbeiana was 4 nmol.

\section{Purification of glucagons}

The glucagon-like immunoreactivity in the extract of $R$. sylvatica pancreas was eluted from the semipreparative Vydac $\mathrm{C}-18$ column as two peaks designated in Fig. $1 A$ as $G_{1}$ (subsequently shown to contain glucagon-36) and $G_{2}$ (subsequently shown to contain glucagon-29). Glucagon-29 was purified to near homogeneity by successive chromatograpies on an analytical Vydac C-4 column (Fig. 3A) and an analytical Vydac phenyl column (Fig. 3B). The final yield of pure peptide was $2.5 \mathrm{nmol}$. Glucagon-36 was purified under the same conditions (chromatograms not shown) and the final yield of pure peptide was 4 nmol.

\section{Structural characterization}

The primary structures of the pyridylethylated A-chains and B-chains of insulins from R. sylvatica, $R$. ridibunda and $R$. catesbeiana were determined by automated Edman degradation and the results are shown in Fig. 4. In each case, it was possible to identify without ambiguity phenylthiohydantoincoupled amino acid for 21 cycles of operation of the sequenator during sequence analysis of the A-chain and for 30 cycles during analysis of the B-chain. The results of amino acid analysis were consistent with the proposed structures and demonstrated that full sequences of the peptides had been obtained. The primary structures of $R$. sylvatica glucagon-29 and glucagon-36 were determined without ambiguity by automated Edman degradation and the results are shown in Fig. 5. The amino acid 

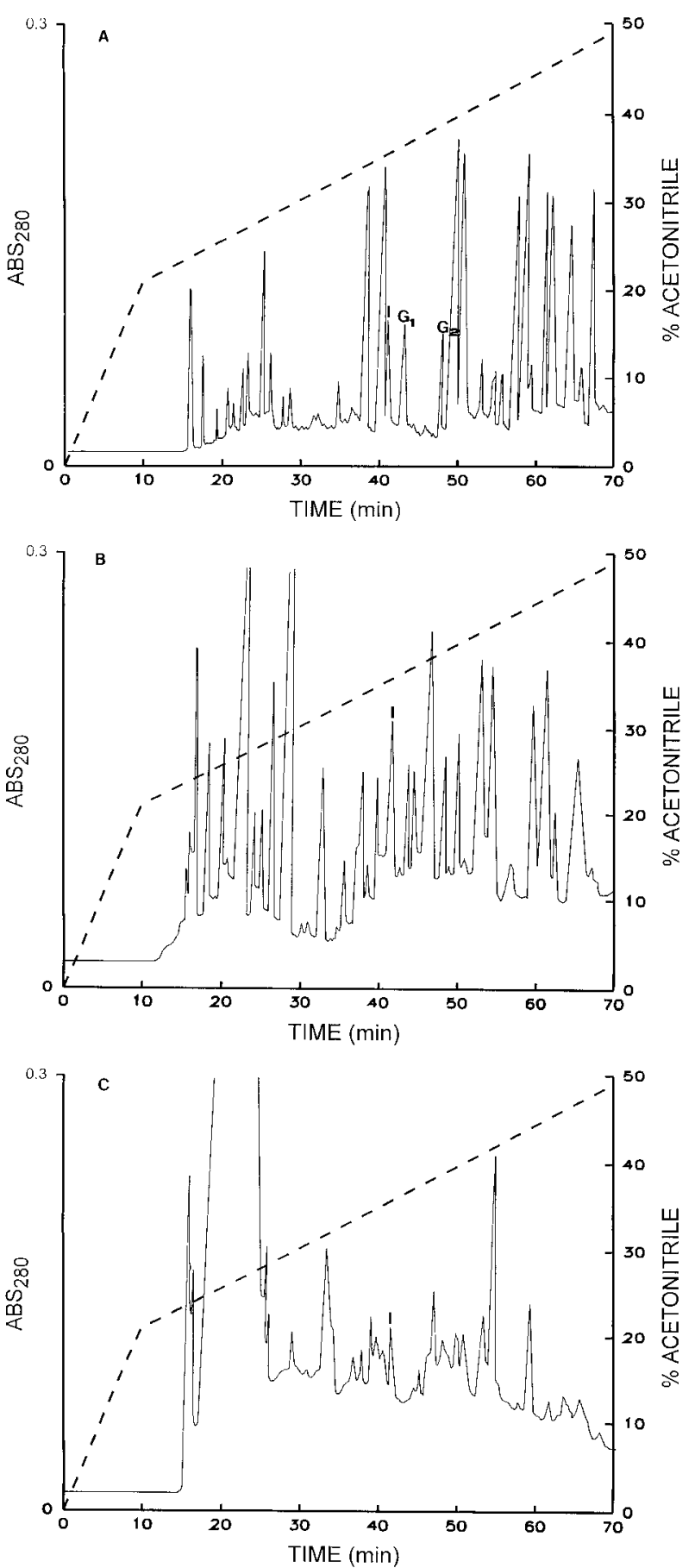

FIGURE 1. Reversed-phase HPLC on semipreparative Vydac C-18 columns of an extract of the pancreas of (A) Rana sylvatica, (B) Rana ridibunda, and (C) Rana catesbeiana. The peak associated with insulin-like immunoreactivity is denoted by I and the peaks containing glucagon-like immunoreactivity are denoted by $\mathrm{G}_{1}$ (glucagon-36) and $\mathrm{G}_{2}$ (glucagon-29). The dashed line shows the concentration of acetonitrile in the eluting solvent.
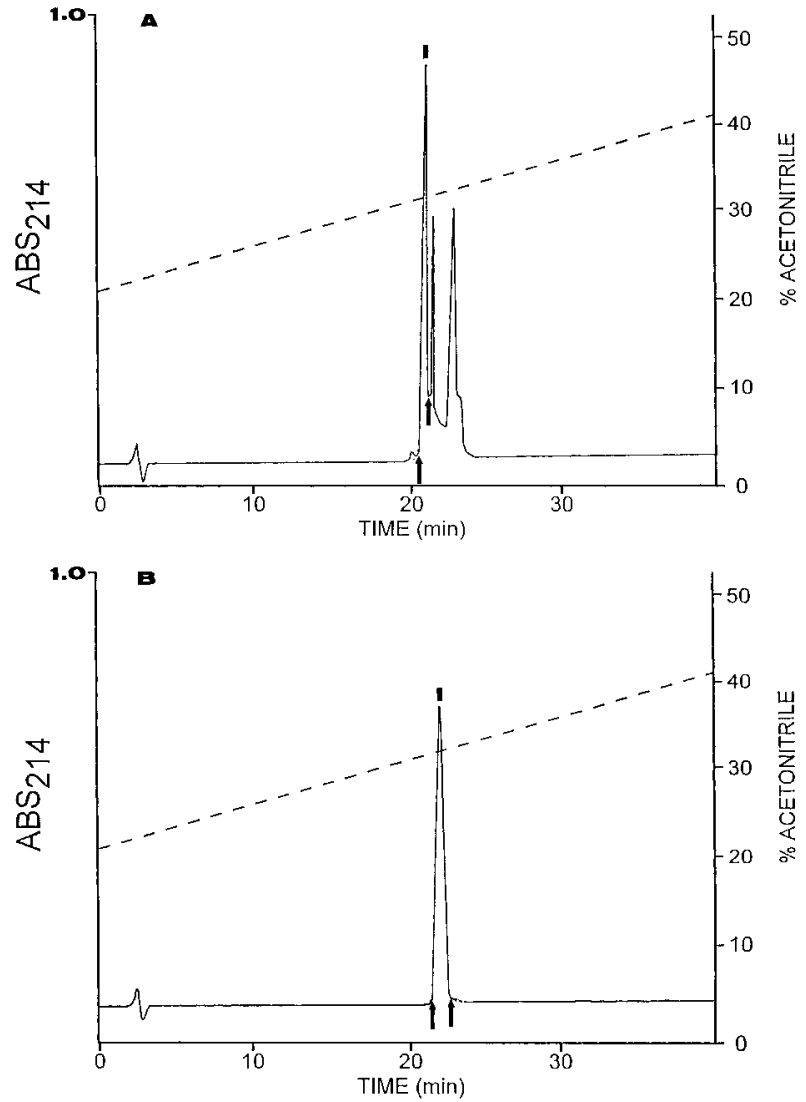

FIGURE 2. Purification by reversed-phase HPLC of Rana sylvatica insulin on (A) analytical Vydac C-4 and (B) analytical Vydac phenyl columns. The peak containing insulin-like immunoreactivity is denoted by I. The arrows show where peak collection began and ended.

compositions of the peptides were consistent with the proposed structures. The data indicated that glucagon-36 represents glucagon-29 extended from its C-terminus by the sequence -Lys-Arg-Ser-GlyGly-Ile-Ser.

\section{DISCUSSION}

The primary structures of insulins isolated from the three species of Ranid frog are compared with human insulin and with the structures of the other known amphibian insulins (the clawed toad Xenopus laevis (Shulinder et al. 1989), the urodeles the three-toed amphiuma Amphiuma tridactylum (Conlon et al. 1996) and the lesser siren Siren intermedia (Conlon et al. 1997), and the caecilian Typhlonectes natans (Conlon et al. 1995) (Fig. 4)). In view of the small amount of pancreatic tissue 

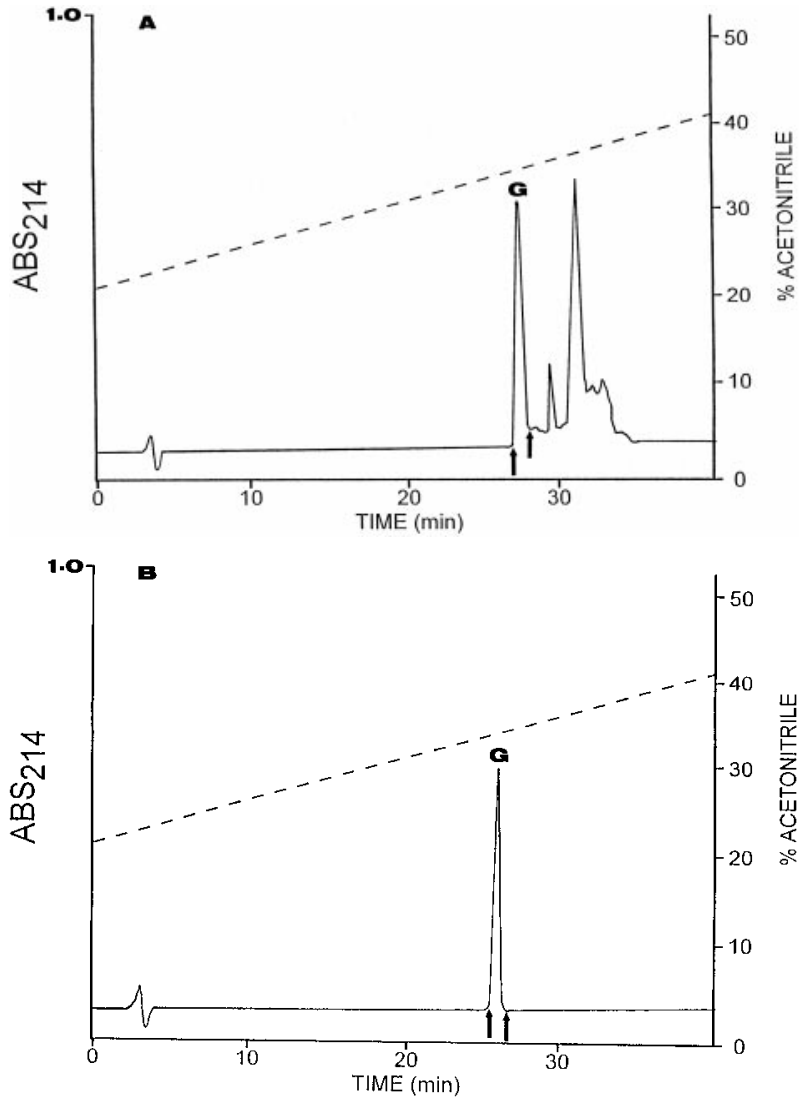

FIGURE 3. Purification by reversed-phase HPLC of Rana sylvatica glucagon-29 on (A) analytical Vydac C-4 and (B) analytical Vydac phenyl columns. The peak containing glucagon-like immunoreactivity is denoted by G. The arrows show where peak collection began and ended.

available $(<0.6 \mathrm{~g})$, it was not possible to purify sufficient insulin from the wood frog to study its biological activity but we speculate that structural features in the molecule may influence conformation and biological potency relative to insulins from the freeze-intolerant Ranids.

Traditionally, the receptor-binding region of human insulin is considered to involve contributions from amino acid residues at positions A1-A3, A5, A19, A21 and B22-B24 (Baker et al. 1988). These residues have been fully conserved in the insulins from the freeze-intolerant Ranids but $R$. sylvatica insulin contains the substitution $($ Asn $\rightarrow$ Ser) at the position corresponding to A21. In the crystal structure of pig insulin, the carboxylate group of A21 forms an ionic bond with B22 arginine and a hydrogen bond bridges the $\alpha$-nitrogen of A21 asparagine with the backbone carbonyl group of B23 glycine (Baker et al. 1988). It has been shown
R. sylvatica
R. ridibunda
R. catesbeiana
Xenopus I
Xenopus II
Amphiuma
Siren
Caecilian
Human

R. sylvatica

R. ridibunda

R. catesbeiana

Xenopus I

Xenopus II

Amphiuma

Siren

Caecilian

Human
A-chain

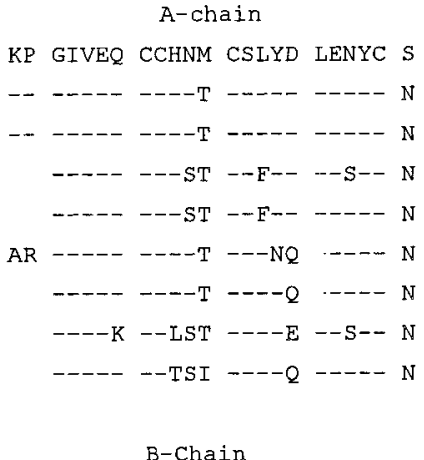

FPNQH LCGSH LVDAL YMVCG DRGFE YSPRS

----Y -..-- --E-- - - -

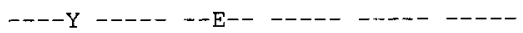

LV--- - - - -- - -E-- -L--- ----- -Y-KV

$-\mathrm{A}----\cdots--\mathrm{E}--\quad-\mathrm{L}-\cdots-----\mathrm{Y}-\mathrm{KI}$

IT--Y -- - - - - E-- - - $---\cdots \cdots$

VP-KP ---A- - - E-- - - F--- -..- -PSST

$\mathrm{IA}-\mathrm{-}-\ldots . .--\mathrm{E}^{--}-\mathrm{L}-\mathrm{A}-\mathrm{A}-\mathrm{-}-\mathrm{T}-\mathrm{K}-$

$-\mathrm{V}----------\mathrm{E}^{--}-\mathrm{L}^{--}-\mathrm{E}-----\mathrm{T}-\mathrm{KT}$
FIGURE 4. A comparison of the primary structure of insulins from Ranid frogs with insulins from other amphibian species and with human insulin. $(-)$ denotes residue identity.
R. sylvatica
HSQGT FTSDY SKYLD SRRAQ DFVQW LMNS
R. catesbeiana
Xenopus

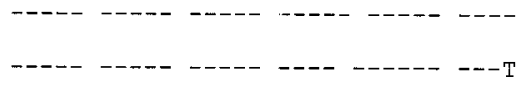
Amphiuma
Turtle

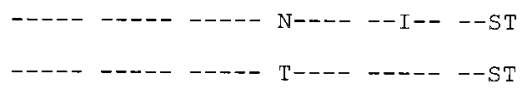
Chicken

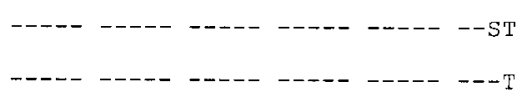
Human

FIGURE 5. A comparison of the primary structures of glucagon from Ranid frogs with glucagons from representatives of other tetrapod species. $(-)$ denotes residue identity.

that these bonds are essential to the formation and maintenance of the biologically active conformation (Markussen et al. 1988). An asparagine residue is present at position A21 in all other vertebrate insulins yet characterized. More recently, however, an alanine scanning mutagenesis study has shown that the substitution (Asn $\rightarrow$ Ala) at A21 in human insulin had only a small effect on binding to the human insulin receptor suggesting that the importance of this residue may have been exaggerated (Kristensen et al. 1997). The same study showed that alanine substitutions at residues A19, B8, B11 and $\mathrm{B} 13$ are disruptive for binding to the insulin 
receptor and so the substitution Glu $\rightarrow$ Asp) at B13 of $R$. sylvatica insulin may affect biological activity. This residue has been strongly conserved in amphibia (Fig. 4) and in mammals, with the exception of the low-potency insulins from hystricomorphs which also contain the Glu $\rightarrow$ Asp mutation (Bajaj et al. 1986).

The residues in human insulin involved in dimer formation (B12, B16, B20, B24, B26 and B28) and hexamer formation (B6, B10, B14, B17, B18, A13, A14) (Baker et al. 1988) have been well conserved in all three Ranid insulins with the exception of the substitution (Leu $\rightarrow$ Met) at B17. The Ranid insulins share with insulins from Xenopus (Shulinder et al. 1989) and the amphiuma (Conlon et al. 1996) the presence of a histidine residue at position A8. This residue, by forming stabilizing structural motifs in the insulin molecule that are of critical importance for receptor recognition, is responsible for the observed increase in binding affinity of these insulins for mammalian insulin receptors. The effect, if any, of the substitution ( $\mathrm{Thr} \rightarrow \mathrm{Met}$ ) at position A12 on the stabilizing motif is not known.

Each Ranid insulin contains a dipeptide extension (Lys-Pro) to N-terminus of the A-chains indicative of an anomalous pathway of post-translational processing of proinsulin. A similar dipeptide extension (Ala-Arg) to the N-terminus of the A-chain was identified in the insulin of the urodele Amphiuma tridactylum (Conlon et al. 1996) and it was speculated that a mutation (Lys $\rightarrow$ Ala) had occurred in the dibasic residue (Lys-Arg) linking the C-peptide region of proinsulin to the A-chain of insulin so that the $\mathrm{PC}-2$ prohormone convertase is obliged to cleave at an alternative site. It is probable, therefore, that a mutation (Arg $\rightarrow$ Pro) has occurred at the same site in the proinsulins from the Ranid frogs. Amphiuma insulin was fivefold more potent than human insulin in inhibiting the binding of radiolabeled human insulin to the human insulin receptor (Conlon et al. 1996) suggesting that the presence of a dipeptide extension does not result in a diminution of biological activity. Insulin isolated from viable specimens of $R$. sylvatica that had been frozen for $24 \mathrm{~h}$ was identical to insulin from control animals, demonstrating that freezing does not affect the pathway of proinsulin processing. In contrast to the anomalous structure of $R$. sylvatica insulin, the amino acid sequences of both glucagon-29 and glucagon-36 are identical to those of the corresponding peptides from $R$. catesbeiana (Pollock et al. 1986). R. sylvatica glucagon differs from human glucagon by a single conservative substitution (Thr $\rightarrow$ Ser) at position 29 (Fig. 5). In general, it appears that glucagon and insulin play similar roles in the regulation of glycogenolysis in amphibia and in mammals. For example, glucagon induces an increase in the concentration of cAMP, conversion of glycogen phosphorylase to the active phosphorylated form (a form) and increases the rate of glycogenolysis in hepatic tissue from the axolotl Ambystoma mexicanum and these effects are counteracted by insulin (Janssens \& Maher 1986). The rise in intracellular glucose concentrations results in allosteric inhibition of phosphorylase a, and insulin by activating protein phosphatase- 1 is responsible for the conversion of phosphorylase to the inactive $b$ form. The mechanism of phosphorylase regulation in the liver of $R$. sylvatica is anomalous (Storey 1990). Exposure to freezing results in an immediate rise in the proportion of phosphorylase in the a form which is followed by a slower rise over several hours in the total activity of the enzyme expressed. This results in a 7 - to 13 -fold increase in active phosphorylase a that supports the massive glucose output of the early hours of freezing (Storey \& Storey 1988). Our present data, demonstrating changes in the amino acid sequence of $R$. sylvatica insulin that are not found in insulins from freeze-intolerant Ranid frogs, lead us to speculate that this insulin has an impaired ability to activate protein phosphatase- 1 and thereby convert phosphorylase a to the inactive form in the liver. In contrast, the primary structure of $R$. sylvatica glucagon is similar to that of other amphibian and mammalian glucagons so that the abilty of the hormone to stimulate glycogenolysis is not impaired.

\section{ACKNOWLEDGEMENTS}

This work was supported by the National Science Foundation (IBN 9418819).

\section{REFERENCES}

Bajaj M, Blundell TL, Horuk R, Pitts JE, Wood SP, Gowan LK, Schwabe C, Wollmer A, Gliemann J \& Gammeltoft S 1986 Coypu insulin. Primary structure, conformation and biological properties of a hystricomorph rodent insulin. European Fournal of Biochemistry 238 345-351.

Baker EN, Blundell TL, Cutfield JF, Cutfield SM, Dodson EJ, Dodson GG, Hodgkin DMC, Hubbard RE, Isacs NW, Reynolds CD, Sakabe K, Sakabe N \& Vijayan NM 1988 The structure $2 \mathrm{Zn}$ pig insulin crystal at $1 \cdot 5 \mathrm{~A}$ resolution. Philosophical Transactions of the Royal Society of London, Series B 319 369-456.

Bidlingmeyer BA, Cohen SA \& Tarvin TL 1984 Rapid analysis of amino acids using pre-column derivatization. Fournal of Chromatography 336 93-104.

Conlon JM \& Thim L 1985 Primary structure of glucagon from an elasmobranchian fish, Torpedo marmorata. General and Comparative Endocrinology 60 398-405. 
Conlon JM, Hilscher-Conklin C \& Boyd SK 1995 Purification and structural characterization of insulin from a caecilian, Typhlonectes natans (Amphibia: Gymnophiona). Peptides 16 1385-1388.

Conlon JM, Cavanaugh ES, Mynarcik DC \& Whittaker J 1996 Characterization of an insulin from the amphiuma (Amphibia: Urodela) with an N-terminally extended A-chain and high receptor-binding affinity. Biochemical Fournal 313 283-287.

Conlon JM, Trauth SE \& Sever DM 1997 Purification and structural characterization of insulin from the lesser siren, Siren intermedia (Amphibia: Caudata). General and Comparative Endocrinology 106 295-300.

Flatt PR \& Bailey CJ 1981 Abnormal plasma glucose and insulin responses in heterozygous $(\mathrm{ob} /+)$ mice. Diabetelogia 20 573-577.

Janssens PA \& Maher F 1986 Glucagon and insulin regulate in vitro hepatic glycogenolysis in the axolotl Ambystoma mexicanum via changes in tissue cyclic AMP concentrations. General and Comparative Endocrinology 61 64-70.

King PA, Rosholt MN \& Storey KB 1993 Adaptations of plasma membrane glucose transport facilitate cyroprotectant distribution in freeze-tolerant frogs. American Fournal of Physiology 265 R1036-R1042.

Kristensen C, Kjeldsen T, Wiberg FC, Schaffer L, Hach M, Havelund S, Bass J, Steiner DF \& Andersen AS 1997 Alanine scanning mutagenesis of insulin. Fournal of Biological Chemistry 272 12978-12983.

Layne JR, Lee RE \& Heil TL 1989 Freezing-induced changes in the heart rate of wood frogs (Rana sylvatica). American Fournal of Physiology 257 R1046-R1049.

Markussen J, Diers I, Hougaard P, Langkjaer L, Norris K, Snel L, Sorensen E \& Voigt HO 1988 Soluble, prolongedacting insulin derivatives. III. Degree of protraction, crystallizability and chemical stability of insulins substituted in positions A21, B13, B23, B27 and B30. Protein Engineering $2157-166$.

Mommsen TP \& Storey KB 1992 Hormonal effects on glycogen metabolism in isolated hepatocytes of a freezetolerant frog. General and Comparative Endocrinology 87 44-53.

Pollock HG, Hamilton JW, Rouse JB, Ebner KE \& Rawitch AB 1986 Isolation of peptide hormones from the pancreas of the bullfrog (Rana catesbeiana). Fournal of Biological Chemistry 263 9746-9751.

Shulinder AR, Bennett C, Robinson EA \& Roth J 1989 Isolation and characterization of two different insulins from an amphibian, Xenopus laevis. Endocrinology 125 469-477.

Storey KB $1987 a$ Organ-specific metabolism during freezing and thawing in a freeze-tolerant frog. American Fournal of Physiology 253 R292-R297.

Storey KB $1987 b$ Glycolysis and the regulation of cryoprotectant synthesis in liver of the freeze-tolerant wood frog. Fournal of Comparative Physiology 157 373-380.

Storey KB 1990 Life in a frozen state: adaptive strategies for natural freeze tolerance in amphibians and reptiles. American Fournal of Physiology 258 R559-R568.

Storey KB \& Storey JM 1985 Triggering of cryoprotectant synthesis by the initiation of ice nucleation in the freezetolerant frog, Rana sylvatica. Fournal of Comparative Physiology 156 191-195.

Storey KB \& Storey JM 1988 Freeze tolerance in animals. Physiological Reviews 68 27-84.

Storey KB \& Mommsen TP 1994 Effects of temperature and freezing on hepatocytes from a freeze-tolerant frog. American Fournal of Physiology 266 R1477-R1482.

Storey KB, McDonald DG, Perry SF, Harris VL \& Storey JM 1992 Effects of freezing on the blood chemistry of the wood frog. Cryogenics Letters 13 363-370.

REVISED MANUSCRIPT RECEIVED 13 January 1998 